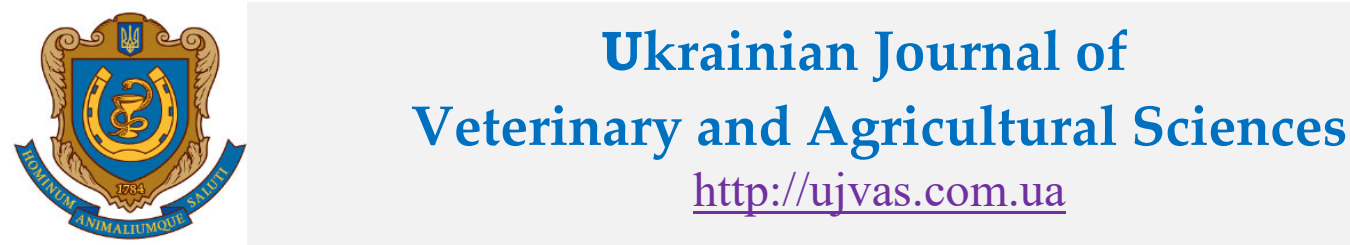

Stepan Gzhytskyi National University of Veterinary Medicine and Biotechnologies Lviv

\begin{tabular}{l|l|ll} 
original article & UDC 636.4 .082 .43 & doi: 10.32718/ujvas3-3.07 & Number 3
\end{tabular}

\title{
Physicochemical properties and chemical composition of muscle tissue of young pigs of large white breed and their correlation with some serum enzymes
}

\author{
V. I. Khalak ${ }^{1}$, B. V. Gutyj ${ }^{2}$ \\ ${ }^{1}$ State Institution Institute of grain crops of NAAS, V. Vernadsky Str., 14, Dnipro, 49027, Ukraine \\ ${ }^{2}$ Stepan Gzhytskyi National University of Veterinary Medicine and Biotechnologies Lviv, Pekarska Str., 50, Lviv, 79010, \\ Ukraine
}

\begin{tabular}{|c|c|}
\hline $\begin{array}{l}\text { Article info } \\
\text { Received 20.07.2020 } \\
\text { Received in revised form } \\
\quad 25.08 .2020 \\
\text { Accepted } 26.08 .2020\end{array}$ & \\
\hline $\begin{array}{l}\text { Correspondence author } \\
\text { Viktor Khalak } \\
\text { Tel.: +38-067-892-44-04 } \\
\text { E-mail:v16kh91@gmail.com }\end{array}$ & \\
\hline $\begin{array}{l}2020 \text { Khalak V., Gutyj B. This } \\
\text { open-access article distributed } \\
\text { the terms of the Creative Com } \\
\text { Attribution License, which pe } \\
\text { unrestricted use, distribution, } \\
\text { reproduction in any med } \\
\text { provided the original author } \\
\text { source are credited. }\end{array}$ & $\begin{array}{l}\text { is an } \\
\text { under } \\
\text { mons } \\
\text { rmits } \\
\text { and } \\
\text { dium, } \\
\text { and }\end{array}$ \\
\hline$(\mathrm{cc}) \mathrm{Br}_{\mathrm{Br}}$ & \\
\hline $\begin{array}{l}\text { Contents } \\
\text { 1. Introduction ................ } \\
\text { 2. Materials and methods ...... } \\
\text { 3. Results and discussion ...... } \\
\text { 4. Conclusions ................. } \\
\text { References .................. }\end{array}$ & $\begin{array}{l}34 \\
35 \\
35 \\
37 \\
37\end{array}$ \\
\hline
\end{tabular}

References ...................... 37

37

\begin{abstract}
The aim of the study was to investigate the biochemical parameters of blood serum, physicochemical properties and chemical composition of muscle tissue of young white pigs of English origin, as well as to calculate the level of correlations between the main quantitative traits. The experimental part of the work was carried out in LTd "AF" Dzerzhynets" Dnipropetrovsk region, Research Center for Biosafety and Environmental Control of Agricultural Resources Dnipro State Agrarian and Economic University, Ltd "Globinsky Meat Plant" Poltava region, laboratory of zootechnical analysis of the Institute of Pig Breeding and Agriculture and livestock laboratories of the Institute of Cereals NAAS. Blood sampling for biochemical studies was performed in 5-month-old animals, serum activity of aspartate aminotransferase (AST), alanine aminotransferase (ALT), alkaline phosphatase and $\alpha$ amylase was determined. Physicochemical properties and chemical composition of the longest muscle of the back (m. Longissimus dorsi) were studied on the indicators of "moisture holding capacity, \%", "color intensity, units. ext. × 1000", "tenderness", c, "fat content, \%", "total moisture content, \%", "protein content, \%", "heat loss, \%", and "energy value of muscle tissue, kcal". It was found that the biochemical parameters of blood serum of young pigs of large white breed at 5 months of age correspond to the physiological norm of clinically healthy animals. Thus, the activity of aspartate aminotransferase (AST) is $1.33 \pm 0.074 \mathrm{mmol} / \mathrm{h} / \mathrm{l}$, alanine aminotransferase (ALT) $1.87 \pm 0.063 \mathrm{mmol} / \mathrm{h} / \mathrm{l}$, alkaline phosphatase $-291.99 \pm 12.517 \mathrm{IU} / \mathrm{l}, \alpha$-amylase $-169.82 \pm 5.005 \mathrm{~g} / \mathrm{h} \times 1$. Studies of physicochemical properties and chemical composition of samples of the longest back muscle of young pigs of large white breed show that the number of high quality samples in terms of "moisture holding capacity, \%" is equal to $12.0 \%$, "color intensity, units. ext. $\times 1000$ " $-16.0 \%$, "tenderness, $c "-12.0 \%$ and "fat content, $\% "$ $16.0 \%$. Significant correlations were established between the following pairs of features: moisture holding capacity, $\% \times$ protein content, $\%(-0.484 \pm 0.1825, \operatorname{tr}=2.65)$, moisture holding capacity, $\% \times$ heat $10 s s, \%-0.416$ $\pm 0.1896, \operatorname{tr}=2.19)$, fat content, $\% \times$ moisture holding capacity, $\%,(-0.450 \pm 01862, \operatorname{tr}=2.42)$, fat content, $\% \times$ energy value, $\mathrm{kcal}(0.836 \pm 0.1144, \operatorname{tr}=7.31)$, alanine aminotransferase $(\mathrm{ALT})$ activity, $\mathrm{mmol} / \mathrm{h} / \mathrm{l} \times \mathrm{pH}$, units of acidity, $(0.443 \pm 0.1859, \operatorname{tr}=2.37)$, alkaline phosphatase activity, units $/ \times$ color intensity, units. ext. $\times 1000$ $(-0.483 \pm 0.1826, \operatorname{tr}=2.65)$, alkaline phosphatase activity, units $/ 1 \times \mathrm{P}, \%(0.484 \pm 0.1825, \operatorname{tr}=2.65)$.
\end{abstract}

Key words: young pigs, breed, serum biochemical parameters, physicochemical properties and chemical composition of muscle tissue, variability, correlation.

\section{Citation:}

Khalak, V. I., \& Gutyj, B. V. (2020). Physicochemical properties and chemical composition of muscle tissue of young pigs of large white breed and their correlation with some serum enzymes. Ukrainian Journal of Veterinary and Agricultural Sciences, 3(3), 34-38.

\section{Introduction}

Intensification of the pig industry involves, along with improving the conditions of keeping and feeding the use of highly productive breeds, types and lines in the selection process, as well as the development and implementation of effective methods for assessing growth and development in early ontogeny, reproductive capacity of sows and breeding boars, fattening and meat qualities of their offspring (Kabanov, 2009; Allison \& Laven, 2000; Aknevs'kyy et al., 2013; Khalak et al., 2020).

An important issue is the study of interior features, data analysis and their use as markers of early prediction of signs of fattening, slaughter, meat qualities, as well as physicochemical and chemical properties of muscle tissue and sebum (Lugovoy et al., 2017; Tserenyuk, 2018; Kramarenko et al., 2018; 2019; Martyshuk et al., 2019; 2020; Vuhliar, 2020; Novakovska, 2020; Khalak \& Gutyj, 2020).

The aim of the study was to investigate the biochemical parameters of blood serum, physicochemical properties and chemical composition of muscle tissue of young white pigs of English origin, as well as to calculate the level of correlations between the main quantitative traits. 


\section{Materials and methods}

The study was conducted in the conditions of breeding facilities for reproducting large white pigs at Ltd "AF Dzerzhynets" Dnipropetrovsk region, Research Center for Biosafety and Environmental Control of Agricultural Resources of the Dnipro State Agrarian and Economic University, Ltd "Globinsky Meat Plant" Poltava region, laboratory Institute of Pig Breeding and Agroindustrial Production of NAAS and Animal Husbandry Laboratory of the State Institution Institute of Grain Crops of NAAS. The work was performed according to the research program of NAAS № 30 "Pig breeding”.

Control fattening of young pigs of this genotype was carried out in the farm in accordance with the requirements of modern research methods in pig breeding.

Sampling of blood from animals of the experimental group was performed at 5 months of age. Serum activity of aspartate aminotransferase (AST), $\mathrm{mmol} / \mathrm{h} / \mathrm{l}$, alanine ami- notransferase (ALT), mmol/h/l, alkaline phosphatase activity, units $/ 1$ and $\alpha$-amylase, $\mathrm{g} / \mathrm{h} \times 1$ (Vlizlo, 2012).

Physicochemical properties and chemical composition of the longest muscle of the back (m. Longissimus dorsi) were studied by the following parameters: $\mathrm{pH}$, acidity units, moisture holding capacity, $\%$, color intensity, units. ext. $\times 1000$, tenderness, $\mathrm{s}$, fat content, $\%$, total moisture, $\%$, protein, $\%$, calcium, \%, phosphorus, \%, heat loss, \%, (Polyvoda, 1976; Polivoda et al., 1977).

The energy value of muscle tissue was calculated by the chemical composition of the average sample of minced meat by the formula:

$$
\mathrm{X}=(\mathrm{C}-(\mathrm{F}+\mathrm{Z})) \times 4.1+\mathrm{F} \times 9.3
$$

where: $\mathrm{X}$ - caloric content $100 \mathrm{~g}$ of meat, cal; $\mathrm{C}$ - the amount of dry matter, g; F - amount of fat, g; $\mathrm{Z}$ - amount of ash, g.

A comprehensive assessment of meat quality was performed according to the method (Table 1) (Polyvoda, 1976).

Table 1

Scale for assessing the quality of meat by physico-chemical parameters

\begin{tabular}{|c|c|c|c|c|c|}
\hline \multirow[b]{2}{*}{ Evaluation } & \multicolumn{5}{|c|}{ Meat quality indicator } \\
\hline & $\begin{array}{l}\text { moisture holding } \\
\text { capacity, } \%\end{array}$ & $\begin{array}{l}\text { color intensity, }(\text { extinction } \\
\text { coefficient } \times 1000)\end{array}$ & $\begin{array}{l}\text { tenderness, } \\
\text { seconds }\end{array}$ & fat, $\%$ & $\begin{array}{l}\text { melting point of } \\
\text { sebum, degrees }\end{array}$ \\
\hline Limits & $46.8-71.8$ & $27-119$ & $5.8-15.5$ & $0.7-4.8$ & $23.5-46.8$ \\
\hline A high quality & 67.0 and more & 83 and more & 7.9 and less & 3.1 and more & - \\
\hline Normal quality & $53.0-66.0$ & $48-82$ & $8.0-12.0$ & $1.2-3.0$ & $32.5-41.5$ \\
\hline Low quality & 52.0 and less & 47 and less & 12.1 and more & 1.1 and less & $\begin{array}{l}41.6 \text { and more } \\
32.4 \text { and less }\end{array}$ \\
\hline
\end{tabular}

The strength of the correlations between traits was determined by the Cheddock scale (Table 2).

\section{Table 2}

Cheddock scale for grading the strength of the correlation between quantitative features

\begin{tabular}{cc}
\hline $\begin{array}{c}\text { The value of the correlation } \\
\text { coefficient }\end{array}$ & Correlation strength \\
\hline $0.1-0.3$ & Weak \\
$0.3-0.5$ & Moderate \\
$0.5-0.7$ & Noticeable \\
$0.7-0.9$ & High \\
$0.9-0.99$ & Very high \\
\hline
\end{tabular}

Biometric processing of the obtained research results was performed according to the method (Lakin, 1990) using the programmable module "Data Analysis" in Microsoft Excel.

\section{Results and discussion}

Studies of biochemical parameters of blood serum of young pigs showed that in animals of large white breed of English origin at 5 months of age the activity of aspartate aminotransferase (AST) is $1.33 \pm 0.074 \mathrm{mmol} / \mathrm{h} / \mathrm{l}$, alanine aminotransferase (ALT) $-1.87 \pm 0.063 \mathrm{mmol} / \mathrm{h} / \mathrm{l}$, alkaline phosphatase $-291.99 \pm 12.517$ units/l and $\alpha$-amylase $169.82 \pm 5.005 \mathrm{~g} / \mathrm{h} \times 1$ (Table 3$)$. These indicators correspond to the physiological norm of clinically healthy animals (Vlizlo, 2012).

Table 3

Biochemical parameters of blood serum of young pigs of the experimental groups, $n=25$

\begin{tabular}{|c|c|c|c|}
\hline \multirow{2}{*}{ Indicators, units of measurement } & \multicolumn{3}{|c|}{ Biometric indicators } \\
\hline & $\overline{\mathrm{X}} \pm S \bar{x}$ & $\sigma \pm \mathrm{S} \sigma$ & $\mathrm{Cv} \pm \mathrm{S}_{\mathrm{Cv}}, \%$ \\
\hline Activity: aspartate aminotransferase AST), mmol/hour/l & $1.33 \pm 0.073$ & $0.36 \pm 0.070$ & $27.06 \pm 3.827$ \\
\hline alanine aminotransferase (ALT), $\mathrm{mmol} / \mathrm{h} / \mathrm{l}$ & $1.87 \pm 0.063$ & $0.32 \pm 0.045$ & $17.11 \pm 2.420$ \\
\hline alkaline phosphatase, units/liter & $291.99 \pm 12.51$ & $62.58 \pm 8.851$ & $21.43 \pm 3.011$ \\
\hline$a$-amylase, $\mathrm{g} / \mathrm{h} \times 1$ & $169.82 \pm 5.005$ & $25.02 \pm 3.538$ & $14.73 \pm 2.083$ \\
\hline
\end{tabular}

In terms of physicochemical properties and chemical composition, the samples of the longest muscle of the back were characterized by the following indicators: moisture holding capacity was $60.10 \pm 0.981 \%$, color intensity $73.60 \pm 2.147$ units. ext. $\times 1000$, tenderness $-9.41 \pm$
$0.283 \mathrm{~s}$, fat content $-2.28 \pm 0.341 \%$ (Table 4$)$. The indicators "total moisture content", "air-dry matter content", "ash content", "protein content", "fat content", "calcium content, $\%$ ", "phosphorus content, \%", respectively, were equal to $74.13 \pm 0.446,27.25 \pm 0.450,1.13 \pm 0.019,22.36 \pm 0.400$, 
$2.28 \pm 0.341,0.045 \pm 0.0011$ and $0.126 \pm 0.0047 \%$. The loss of absolute mass of the muscle tissue sample during heat treatment is $22.36 \pm 0.400 \%$, and its energy value is $21.88 \pm 3.110 \mathrm{kcal}$.

The coefficient of variation of the indicators characteriz- ing the physicochemical properties and chemical composition of the longest back muscle in the animals of the experimental group ranges from 2.49 ( $\mathrm{pH}$, acidity units) to $74.56 \%$ (fat content, \%).

\section{Table 4}

Physico-chemical properties and chemical composition of the longest back muscle of young pigs of large white breed, $\mathrm{n}=25$

\begin{tabular}{|c|c|c|c|}
\hline \multirow{2}{*}{ Indicators, units of measurement } & \multicolumn{3}{|c|}{ Biometric indicators } \\
\hline & $\overline{\mathrm{X}} \pm S \bar{x}$ & $\sigma \pm \mathrm{S} \sigma$ & $\mathrm{Cv} \pm \mathrm{S}_{\mathrm{Cv}}, \%$ \\
\hline $\mathrm{pH}$, units of acidity & $5.62 \pm 0.028$ & $0.14 \pm 0.091$ & $2.49 \pm 0.352$ \\
\hline tenderness, $\mathrm{p}$ & $9.41 \pm 0.283$ & $1.41 \pm 0.199$ & $14.98 \pm 2.118$ \\
\hline moisture holding capacity, $\%$ & $60.10 \pm 0.981$ & $4.90 \pm 0.693$ & $8.15 \pm 1.152$ \\
\hline color intensity, units ext. $\times 1000$ & $73.60 \pm 2.147$ & $10.73 \pm 1.517$ & $14.57 \pm 2.060$ \\
\hline heat treatment losses, $\%$ & $22.03 \pm 0.667$ & $3.33 \pm 0.471$ & $15.11 \pm 2.137$ \\
\hline total moisture & $74.13 \pm 0.446$ & $2.23 \pm 0.315$ & $3.01 \pm 0.425$ \\
\hline air-dry matter & $27.25 \pm 0.450$ & $2.25 \pm 0.318$ & $8.25 \pm 1.167$ \\
\hline ashes & $1.13 \pm 0.019$ & $0.09 \pm 0.012$ & $7.96 \pm 1.125$ \\
\hline protein & $22.36 \pm 0.400$ & $2.00 \pm 0.282$ & $8.94 \pm 1.264$ \\
\hline fat & $2.28 \pm 0.341$ & $1.70 \pm 0.240$ & $74.56 \pm 1.054$ \\
\hline calcium $(\mathrm{Ca})$ & $0.045 \pm 0.0011$ & $0.005 \pm 0.0007$ & $11.11 \pm 1.571$ \\
\hline phosphorus (P) & $0.126 \pm 0.0047$ & $0.023 \pm 0.0032$ & $18.25 \pm 2.581$ \\
\hline Energy value of muscle tissue, kcal & $121.88 \pm 3.110$ & $15.55 \pm 2.199$ & $12.75 \pm 1.773$ \\
\hline
\end{tabular}

According to the scale of meat quality assessment according to physicochemical parameters (Polyvoda, 1976), the number of high quality samples according to the indicators "moisture holding capacity, \%" is equal to $12.0 \%$, "color intensity, units. ext. $\times 1000 "-16.0 \%$, "tenderness, c" $-12.0 \%$ and "fat content, $\% "-16.0 \%$.

Analysis of the data shows that the correlations between physicochemical properties and chemical composition of the longest back muscle (Table 5), physicochemical properties, chemical composition of the longest back muscle and biochemical parameters of serum in young white pigs breed (Table 6) are multidirectional, and vary in strength from weak to moderate.

\section{Table 5}

Correlation coefficient between physicochemical properties and chemical composition of the longest back muscle of young white pigs, $\mathrm{n}=25$

\begin{tabular}{cccc}
\hline \multicolumn{2}{c}{ Features } & \multicolumn{2}{c}{ Biometric indicators } \\
\hline$x$ & $y$ & $\mathrm{r} \pm \mathrm{Sr}$ & $\operatorname{tr}$ \\
\hline & 6 & $0.121 \pm 0.2070$ & 0.58 \\
& 7 & $-0.054 \pm 0.2082$ & 0.26 \\
1 & 8 & $-0.124 \pm 0.2069$ & 0.60 \\
& 9 & $0.119 \pm 0.2070$ & 0.57 \\
& 10 & $-0.141 \pm 0.2064$ & 0.68 \\
& 11 & $-0.160 \pm 0.2058$ & 0.78 \\
& 12 & $-0.207 \pm 0.2039$ & 1.01 \\
\hline & 6 & $0.296 \pm 0.1992$ & 1.49 \\
& 7 & $-0.484 \pm 0.1825^{*}$ & 2.65 \\
& 8 & $-0.361 \pm 0.1945$ & 1.86 \\
& 9 & $-0.416 \pm 0.1896^{*}$ & 2.19 \\
& 10 & $-0.101 \pm 0.2074$ & 0.49 \\
& 11 & $-0.310 \pm 0.1981$ & 1.56 \\
& 12 & $-0.061 \pm 0.2081$ & 0.29 \\
\hline
\end{tabular}

\begin{tabular}{cccc}
\hline & 6 & $0.318 \pm 0.1977$ & 1.61 \\
& 7 & $-0.209 \pm 0.2039$ & 1.02 \\
3 & 8 & $-0.225 \pm 0.2032$ & 1.11 \\
& 9 & $0.176 \pm 0.2053$ & 0.86 \\
& 10 & $-0.275 \pm 0.2005$ & 1.37 \\
& 11 & $-0.021 \pm 0.2085$ & 0.10 \\
& 12 & $0.131 \pm 0.2067$ & 0.63 \\
\hline & 6 & $0.179 \pm 0.2051$ & 0.87 \\
4 & 7 & $-0.086 \pm 0.2077$ & 0.41 \\
& 8 & $0.058 \pm 0.2082$ & 0.28 \\
& 9 & $-0.107 \pm 0.2073$ & 0.52 \\
& 10 & $-0.165 \pm 0.2057$ & 0.80 \\
& 11 & $-0.020 \pm 0.2085$ & 0.10 \\
& 12 & $-0.254 \pm 0.2016$ & 1.25 \\
\hline \multirow{4}{*}{5} & 6 & $-0.450 \pm 0.1862 *$ & 2.42 \\
& 7 & $-0.319 \pm 0.1976$ & 1.61 \\
& 8 & $-0.167 \pm 0.2056$ & 0.81 \\
& 9 & $-0.250 \pm 0.2019$ & 1.24 \\
& 10 & $0.836 \pm 0.1144 * * *$ & 7.31 \\
& 11 & $0.172 \pm 0.2054$ & 0.84 \\
& 12 & $0.178 \pm 0.2051$ & 0.86
\end{tabular}

Note: $1-\mathrm{pH}$, units of acidity, 2 - moisture holding capacity, $\%$, 3 - color intensity, units ext. $\times 1000,4-$ tenderness, s, $5-$ fat content, $\%, 6$ - total moisture content, $\%, 7$ - protein content, $\%$, 8 - ash content, $\%, 9$ - heat loss, $\%, 10$ - energy value, kcal, $11-\mathrm{Ca}, \%, 12-\mathrm{P}, \%, *-\mathrm{P}<0.05, * * *-\mathrm{P}<0.001$.

Significant correlations were established between the following pairs of features: moisture holding capacity, $\% \times$ protein content, $\%(-0.484 \pm 0.1825, \operatorname{tr}=2.65)$, moisture holding capacity, $\% \times$ heat loss, $\%-0.416 \pm 0.1896$, $\operatorname{tr}=2.19)$, fat content, $\% \times$ moisture holding capacity, $\%$, $(-0,450 \pm 0.1862, \operatorname{tr}=2.42)$, fat content, $\% \times$ energy value, kcal $(0,836 \pm 0,1144, \operatorname{tr}=7.31)$, alanine aminotransferase (ALT) activity, $\mathrm{mmol} / \mathrm{h} / \mathrm{l} \times \mathrm{pH}$, units of acidity, $(0.443 \pm$ $0.1859, \operatorname{tr}=2.37)$, alkaline phosphatase activity, units $/ 1 \times$ color intensity, units. ext. $\times 1000(-0.483 \pm 0.1826$, $\operatorname{tr}=2.65)$, alkaline phosphatase activity, units $/ 1 \times \mathrm{P}, \%$ $(0.484 \pm 0.1825, \operatorname{tr}=2.65)$. 


\section{Table 6}

Correlation coefficient between biochemical parameters of blood serum, physicochemical properties and chemical composition of the longest back muscle of young pigs of large white breed, $\mathrm{n}=25$

\begin{tabular}{|c|c|c|c|}
\hline \multicolumn{2}{|c|}{ Features } & \multicolumn{2}{|c|}{ Biometric indicators } \\
\hline$x$ & $y$ & $\mathrm{r} \pm \mathrm{Sr}$ & $\operatorname{tr}$ \\
\hline \multirow{12}{*}{1} & 5 & $0.165 \pm 0.2057$ & 0.80 \\
\hline & 6 & $0.066 \pm 0.2081$ & 0.32 \\
\hline & 7 & $0.301 \pm 0.1988$ & 1.51 \\
\hline & 8 & $-0.104 \pm 0.2074$ & 0.50 \\
\hline & 9 & $0.255 \pm 0.2016$ & 1.26 \\
\hline & 10 & $-0.292 \pm 0.1994$ & 1.46 \\
\hline & 11 & $0.026 \pm 0.2084$ & 0.12 \\
\hline & 12 & $0,190 \pm 0.2047$ & 0.93 \\
\hline & 13 & $-0.027 \pm 0.2084$ & 0.13 \\
\hline & 14 & $-0.283 \pm 0.2000$ & 1.42 \\
\hline & 15 & $-0.030 \pm 0.2084$ & 0.14 \\
\hline & 16 & $0.178 \pm 0.2052$ & 0.87 \\
\hline \multirow{12}{*}{2} & 5 & $0.443 \pm 0.1859 *$ & 2.37 \\
\hline & 6 & $0.013 \pm 0.02085$ & 0.06 \\
\hline & 7 & $0.283 \pm 0.2000$ & 1.42 \\
\hline & 8 & $-0.174 \pm 0.2053$ & 0.85 \\
\hline & 9 & $-0.184 \pm 0.2050$ & 0.90 \\
\hline & 10 & $0.084 \pm 0.2078$ & 0.40 \\
\hline & 11 & $0.126 \pm 0.2069$ & 0.61 \\
\hline & 12 & $0.215 \pm 0.2036$ & 1.06 \\
\hline & 13 & $0.012 \pm 0.2085$ & 0.06 \\
\hline & 14 & $0.159 \pm 0.2059$ & 0.77 \\
\hline & 15 & $0.124 \pm 0.2069$ & 0.60 \\
\hline & 16 & $0.392 \pm 0.1918$ & 2.04 \\
\hline \multirow{12}{*}{3} & 5 & $0.018 \pm 0.2085$ & 0.09 \\
\hline & 6 & $0.120 \pm 0.2070$ & 0.58 \\
\hline & 7 & $0.483 \pm 0.1826^{*}$ & 2.65 \\
\hline & 8 & $0.105 \pm 0.2074$ & 0.51 \\
\hline & 9 & $-0.051 \pm 0.2082$ & 0.24 \\
\hline & 10 & $-0.116 \pm 0.2071$ & 0.56 \\
\hline & 11 & $0.118 \pm 0.2071$ & 0.57 \\
\hline & 12 & $-0.158 \pm 0.2059$ & 0.77 \\
\hline & 13 & $0.135 \pm 0.2066$ & 0.65 \\
\hline & 14 & $0.050 \pm 0.2083$ & 0.24 \\
\hline & 15 & $0.140 \pm 0.2065$ & 0.68 \\
\hline & 16 & $0.484 \pm 0.1825^{*}$ & 2.65 \\
\hline \multirow{12}{*}{4} & 5 & $-0.129 \pm 0.2068$ & 0.62 \\
\hline & 6 & $-0.062 \pm 0.2081$ & 0.30 \\
\hline & 7 & $0.177 \pm 0.2052$ & 0.86 \\
\hline & 8 & $-0.081 \pm 0.2078$ & 0.39 \\
\hline & 9 & $0.112 \pm 0.2072$ & 0.54 \\
\hline & 10 & $-0.068 \pm 0.2080$ & 0.33 \\
\hline & 11 & $-0.090 \pm 0.2077$ & 0.43 \\
\hline & 12 & $0.078 \pm 0.2079$ & 0.38 \\
\hline & 13 & $-0.028 \pm 0.2084$ & 0.13 \\
\hline & 14 & $-0.122 \pm 0.2070$ & 0.59 \\
\hline & 15 & $0.258 \pm 0.2015$ & 1.28 \\
\hline & 16 & $0.287 \pm 0.1997$ & 1.44 \\
\hline
\end{tabular}

Note: 1 - aspartate aminotransferase (AST) activity, $\mathrm{mmol} / \mathrm{h} / \mathrm{l}$, 2 - alanine aminotransferase (ALT) activity, $\mathrm{mmol} / \mathrm{h} / \mathrm{l}, 3$ - alkaline phosphatase activity, units/l, $4-\mathrm{a}$-amylase activity, $\mathrm{g} / \mathrm{h} \times 1,5-\mathrm{pH}$, units of acidity, 6 - moisture holding capacity, $\%, 7$ - color intensity, units ext. $\times 1000,8-$ tenderness, s, 9 - total moisture content, $\%, 10$ - fat content, $\%, 11$ - protein content, $\%, 12$ - heat loss, $\%$, 13 - ash content, $\%, 14$ - energy value, kcal, 15 - calcium (Ca), \%, 16 - phosphorus $(\mathrm{P}), \%, *-\mathrm{P}<0.05$.

\section{Conclusions}

1. According to the results of research it is established that the biochemical parameters of the serum of young pigs correspond to the physiological norm of clinically healthy animals of this species and age.

2. The number of samples of the longest back muscle of high quality in terms of "moisture holding capacity" is 3 $(12 \%)$, "fat content" - $4(16 \%)$, "tenderness" - $3(12 \%)$ and "color intensity" $-4(16 \%)$.

3. Effective biochemical markers for early prediction of high quality meat by active acidity $(\mathrm{pH})$ and color intensity are the activity of alanine aminotransferase (ALT) and alkaline serum phosphatase of young pigs of large white breed of English origin at 5 months of age.

Prospects for further research. Further work in this area involves the study of fattening and meat qualities of young pigs of different intra-breed and inter-breed combinations, taking into account their genotype for some DNA markers.

\section{References}

Aknevs'kyy, Yu. P., Buslyk, T. V., Hryshyna, L. P., \& Balats'kyy, V. M. (2013). Vplyv polimorfizmu henu retseptora melanokortynu - 4 (MS4R) na vidhodivel'ni ta m'yasni yakosti pomisnykh, hibrydnykh i chystoporidnykh svyney velykoyi biloyi porody. Svinarstvo, 63, 28-37 (in Ukrainian).

Allison, R. D., \& Laven, R. A. (2000). Effect of vitamin E suplementation on the health and fertility of dairy cows: a review. Vet. Rec., 147(25), 703-708. URL: https://pubmed.ncbi.nlm. nih.gov/11140928.

Kabanov, V. (2009). Biologicheskiye osnovy povysheniya intensivnosti svinovodstva. Svinarstvo, 2, 27-28 (in Russian).

Khalak, V. I., \& Gutyj, B. V. (2020). Signs of reproductive qualities of sows of different types of adaptation, their variability and correlation. Scientific Messenger of Lviv National University of Veterinary Medicine and Biotechnologies. Series: Agricultural sciences, 22(92), 35-41. doi: 10.32718/nvlvet-a9207.

Khalak, V., Gutyj, B., Bordun, O., Ilchenko, M., \& Horchanok, A. (2020). Effect of blood serum enzymes on meat qualities of piglet productivity. Ukrainian Journal of Ecology, 10(1), 158161. doi: 10.15421/2020 25.

Khalak, V., Gutyj, B., Bordun, O., Horchanok, A., Ilchenko, M., Smyslov, S., Kuzmenko, O., \& Lytvyshchenko, L. (2020). Development and reproductive qualities of sows of different breeds: innovative and traditional methods of assessment. Ukrainian Journal of Ecology, 10(2), 356-360. doi: 10.15421/2020 109.

Kramarenko, S. S., Lugovoy, S. I., Kharzinova, V. R., Lykhach, V., Kramarenko, A. S., \& Lykhach, A. V. (2018). Genetic diversity of Ukrainian local pig breeds based on microsatellite markers. Regulatory Mechanisms in Biosystems, 9(2), 177 182. doi: $10.15421 / 021826$

Kramarenko, S., Lugovoy, S., Lykhach, A., Kramarenko, A., \& Lykhach, V. (2018). A comparative study of the reproductive traits and clustering analysis among different pig breeds. Scientific Messenger of LNU of Veterinary Medicine and Biotechnologies. Series: Agricultural Sciences, 20(84), 21-26. doi: 10.15421/nvlvet8404.

Kramarenko, S., Lugovoy, S., Lykhach, A., Kramarenko, A., Lykhach, V., \& Slobodianyk, A. (2019). Effect of genetic and non-genetic factors on the reproduction traits in Ukrainian Meat sows. Scientific Messenger of LNU of Veterinary Medicine and Biotechnologies. Series: Agricultural Sciences, 21(90), 3-8. doi: 10.32718/nvlvet-a9001.

Lakin G. F. (1990). Biometriya. Moskva: Vysshaya shkola (in Russian).

Lugovoy, S., Kramarenko, S., \& Lykhach, V. (2017). Genetic polymorphism of the Landrace pig based on microsatellite markers. Scientific Messenger of LNU of Veterinary Medicine 
and Biotechnologies. Series: Agricultural Sciences, 19(74), 63-66. doi: 10.15421/nvlvet7414.

Martyshuk, T. V., Gutyj, B. V., Zhelavskyi, M. M., Midyk. S. V., Fedorchenko, A. M., Todoriuk, V. B., Nahirniak, T. B., Kisera, Ya. V., Sus, H. V., Chemerys, V. A., Levkivska, N. D., \& Iglitskej, I. I. (2020). Effect of Butaselmevit-Plus on the immune system of piglets during and after weaning. Ukrainian Journal of Ecology, 10(2), 347-352. doi: 10.15421/2020 106.

Martyshuk, T. V., Hutyi, B. V., Khalak, V. I., Stadnytska, O. I., \& Todoriuk, V. B. (2019). Stan imunnoi systemy porosiat za dii kormovoi dobavky "Butaselmevit-plius". Visnyk Poltavskoi derzhavnoi ahrarnoi akademii, 4, 116-125. doi: 10.31210/visnyk2019.04.14.

Novakovska, V. (2020). Productivity of pigs when feeding celluloseamylolytic additive. Scientific Messenger of LNU of Veterinary Medicine and Biotechnologies. Series: Agricultural Sciences, 22(92), 76-80. doi: 10.32718/nvlvet-a9213.
Polivoda, A. M., Strobykina, R. V., \& Lyubetskiy, M. D. (1977). Metodika otsenki kachestva produktsii uboya u sviney. Metodiki issledovaniy po svinovodstvu. Khar'kov, 48-57 (in Russian).

Polyvoda, A. M. (1976). Otsinka yakosti svynyny za fizykokhimichnymy pokaznykamy. Svynarstvo, 24, 57-62 (in Ukrainian)

Tserenyuk, O. M. (2018). Metodolohiya vyznachennya efektu heterozysu v svynarstvi. Scientific and technical bulletin of IL $N A A S, 119,173-184$ (in Ukrainian).

Vlizlo, V. V. (2012). Laboratorni metody doslidzhen u biolohiyi, tvarynnytstvi ta veterynarniy medytsyni. Spolom, Lviv (in Ukrainian).

Vuhliar, V. (2020). Morphological indicaters of the gastrointestinal tract of young pigs during feeding of the PVMS "Efiprot". Scientific Messenger of LNU of Veterinary Medicine and Biotechnologies. Series: Agricultural Sciences, 22(92), 71-75. doi: 10.32718/nvlvet-a9212. 